\title{
Regulation of Tissue Engineered Devices in some Latin American Countries: Development and External Influences*
}

Reglamentación de dispositivos de ingeniería tisular en algunos países Latinoamericanos: desarrollo e influencias externas Regulamentação de dispositivos de engenharia de tecidos no alguns países da América Latina: desenvolvimento e influências externas Fecha de recepción: 20-10-2018 | Fecha de aceptación: 30-12-2018

\author{
Catalina Pineda Molina ${ }^{a}$ \\ McGowan Institute of Regenerative Medicine, University of Pittsburgh, Pittsburgh, PA, United \\ States. https://orcid.org/0000-0001-7710-6119 \\ *Investigación original.
}

Correspondencia: ${ }^{a}$ CAP131@ pitt.edu

doi: https://doi.org/10.11144/Javeriana.uo37-79.rted 
Cómo citar: Pineda Molina C. Regulation of tissue engineered devices in some Latin American countries: development and external influences. Univ Odontol. 2018 Jul-Dec; 37(79). https://doi.org/10.11144/Javeriana.uo37-79.rted

\section{ABSTRACT}

Background: Regulation of tissue engineering products, whose purpose is to temporarily replace organs or tissues, should be included in regulatory frameworks of medical devices. Purpose: To review the current regulatory policies for medical devices (especially tissue engineering products) in 5 Latin American countries. Also, to analyze the influence that international organizations and countries with global technological power exert on national policies. Methods: Top-down and horizontal diffusion models were used to analyze how regulatory policies have reached Brazil, Colombia, Ecuador, Mexico, and Peru. The health systems of these countries are considerably different and reveal the different ways the inclusion of tissue engineering products has taken in the regulation and technological adaptation systems in the region. Results: Technological appropriation processes used to classify medical devices in a comprehensive way differs among the countries analyzed. None of them define tissue engineering products. A pattern of top-down diffusion associated with the regulations studied was found. Likewise, horizontal diffusion is part of a regional effort to facilitate the commercialization of medical products. Conclusion: Medical device regulation systems require adjustments to include tissue engineering-derived products. Each country has the potential of taking advantage of local institutions and regional and interregional coalitions to improve current regulation and prepare their health care systems for the arrival of tissue engineering products. 


\section{Keywords}

Brazil; classification; Colombia; commercialization; Ecuador; health regulatory policies; Latin America; medical devices; Mexico; Peru; product; public policy; public policy studies; regulation; tissue engineered product; tissue engineering

\section{RESUMEN}

Antecedentes: La regulación de los productos de ingeniería de tejidos, cuyo propósito es remplazar temporalmente órganos o tejidos, debe incluirse en los marcos reglamentarios de los dispositivos médicos. Objetivo: Revisar las políticas de reglamentación actual de dispositivos médicos (en especial los productos de ingeniería tisular) en 5 países latinoamericanos. Se analiza, asimismo, la influencia que organizaciones internacionales y países con poder tecnológico mundial ejercen en las políticas nacionales. Métodos: Se utilizaron modelos de difusión vertical descendente y horizontal para analizar cómo las políticas de regulación han llegado a Brasil, Colombia, Ecuador, México y Perú. Los sistemas de salud de estos países presentan diferencias considerables que revelan las distintas formas que ha tomado la inclusión de los productos de ingeniería de tejidos en los sistemas de regulación y adaptación tecnológica en la región. Resultados: Los procesos apropiación tecnológica empleada para clasificar los dispositivos médicos de manera integral difiere entre los países analizados. Ninguno de ellos define productos de ingeniería tisular. También se encontró un patrón de difusión descendente asociado a las regulaciones estudiadas. De la misma forma, se está aplicando una difusión horizontal como un esfuerzo regional para facilitar la comercialización de productos médicos. Conclusión: Los sistemas de regulación de dispositivos 
médicos requieren ajustes para incluir los productos derivados de ingeniería de tejidos. Cada país tiene el potencial de aprovechar las instituciones locales y las coaliciones regionales e interregionales para mejorar la regulación actual y preparar al sistema de salud para la llegada de productos de ingeniería tisular.

\section{Palabras clave}

América Latina; Brasil; clasificación; Colombia; comercialización; dispositivos médicos; Ecuador; estudios de políticas públicas; ingeniería tisular; México; Perú; política pública; políticas de reglamentación en salud; producto; producto de ingeniería tisular; reglamentación

\section{ABSTRATO}

Antecedentes: A regulamentação de produtos de engenharia de tecidos, cujo objetivo é substituir temporariamente órgãos ou tecidos, deve ser incluída nas estruturas reguladoras de dispositivos médicos. Objetivo: Revisar as atuais políticas regulatórias para dispositivos médicos (especialmente produtos de engenharia de tecidos) em 5 países da América Latina. Além disso, analisar a influência que organizações internacionais e países com poder tecnológico global exercem sobre as políticas nacionais. Métodos: Modelos top-down e horizontal de difusão foram utilizados para analisar como as políticas regulatórias alcançaram o Brasil, a Colômbia, o Equador, o México e o Peru. Os sistemas de saúde desses países são consideravelmente diferentes e revelam as diferentes formas de inclusão dos produtos de engenharia de tecidos nos sistemas de regulação e adaptação tecnológica da região. Resultados: Os processos de apropriação tecnológica utilizados para classificar os dispositivos médicos de forma abrangente diferem entre os países analisados. 
Nenhum deles define produtos de engenharia de tecidos. Um padrão de difusão top-down associado às regulamentações estudadas foi encontrado. Da mesma forma, a difusão horizontal faz parte de um esforço regional para facilitar a comercialização de produtos médicos. Conclusãa: Os sistemas de regulação de dispositivos médicos requerem ajustes para incluir produtos derivados de engenharia de tecidos. Cada país tem o potencial de aproveitar as instituições locais e as coalizões regionais e inter-regionais para melhorar a regulamentação atual e preparar seus sistemas de saúde para a chegada de produtos de engenharia de tecidos.

\section{Palavras-Chave}

classificação; Brasil; Colômbia; comercialização; Ecuador; engenharia de tecidos; América Latina; dispositivos médicos; México; Peru; políticas publicas; políticas reguladoras de saúde; Produto de engenharia de tecidos

\section{INTRODUCTION}

During the last 20 years, new approaches in tissue engineering have emerged as an alternative to functionally restore or replace damaged organs in the human body (1). Post-industrialized countries such as the United States, the United Kingdom, some members from the European Union, and Japan have led most of the advances in tissue engineering applications. Lawmakers, public and private organizations, and researchers in these countries have worked in both product development and regulatory policies, aiming to control the commercialization of tissue engineered products and to define their path from the bench to the bed side. Thus, the inclusion of regulatory 
policies operates along with the development of new technologies, warranting the evaluation of risks and benefits, as well as ensuring the efficacy of treatments and security of patients.

In Latin American countries, research, development, and commercialization of tissue engineered products are more limited than in their technologically-advanced counterparts, in part due to high investments and elevated technological resources needed for the manufacturing and evaluation of these products. Clinical applications of tissue engineered products face numerous challenges in Latin America due to their associated costs and the lack of coverage by health systems. However, several researchers and local institutions are developing alternative treatments to injuries that otherwise could not be treated by conventional means $(2,3)$.

Despite these efforts, the crosstalk between innovation in tissue engineering and regulation of new products in health care systems has been a neglected issue in studies and discussions about the tissue engineered devices in Latin America. The present article contributes to this inquiry by introducing tissue engineered products and providing a comparative analysis of the regulatory systems for medical devices (specifically tissue engineered products) among a subgroup of Latin American countries. Regulatory frameworks of Brazil, Colombia, Ecuador, Mexico, and Peru are compared herein. These countries provide a representative sample of different health systems in emerging countries, revealing the differential methods of how tissue engineered products have been included in the health systems throughout the region.

\section{Tissue Engineered Derived Products: Definition, Components, and Factors}


The field of tissue engineering has emerged as an interdisciplinary area that combines efforts from biology, medical sciences, and engineering to design and produce functional substitutes of damaged tissues/organs that, due to their extent, cannot be repaired by their own biologic system (4). Tissue engineering applications are of particular interest as an alternative to organ donation strategies, which have been associated with disadvantages in terms of long-life immunosuppression and a limited number of organ donors, among others. Tissue engineered products are intended as temporary substitutes that provide mechanical and functional support while inducing the reparative process within the tissue. For instance, they consist ideally of a degradable scaffold material to bring the required three-dimensional structure, an adequate source of cells, and bioactive molecules, all of which are employed individually or in combination (1). For this reason, tissue engineering applications can have cell-based approaches, as occur with stem cell injections (5), whereas other applications have scaffold-based approaches, in which an in vivo cell infiltration is expected (6). More complex applications involve the implantation of already cell-seeded scaffold materials (7).

Each constituent of the tissue engineered product has important considerations that should be taken into account and that should be a matter of strict regulation to ensure successful clinical applications (8). First, scaffold materials, which can be produced from synthetic (e.g., polymers), biosynthetic (e.g., polyhydroxyalcanoates), or natural (e.g., xenogeneic or allogeneic extracellular matrix-derived scaffolds) sources, are chemically and structurally different, and therefore could positively or negatively be associated with distinctive responses within the body (9). Factors such as the host response to the implanted scaffold material and the biocompatibility should be evaluated before any intended clinical application (10). The host response in general and in 
particular the plasticity of macrophages interacting with the scaffold materials, are the determinant factors defining long-term outcomes of site appropriate functional tissue remodeling vs. foreign body reaction (11). The term biocompatibility refers to the ability of the implanted scaffold material to perform a tissue-specific function without eliciting a detrimental immune host response, characterized by chronic inflammation and development of a foreign body reaction, which ultimately can influence the failure of the tissue engineered product (11-13).

Second, it has to be recognized that the inclusion of cells within the tissue engineered product increases the complexity of the clinical approaches. When cells are seeded on the scaffold material prior to implantation, an adequate cell source (i.e., autologous vs. heterologous stem cells), the mechanisms for vascularization, and the risks of cell manipulation are among the factors that should be considered (14). Lastly, addition of bioactive molecules such as cytokines, growth factors, and differentiation-stimulating factors, which are needed to promote cell migration and differentiation, also require a detailed attention. The use of high doses and their release in the circulatory system might have adverse effects in other tissues, raising questions about the safety of the patient receiving the implant (15).

Based on the combinatorial options of tissue engineered components, the required regulatory pathways to commercialize tissue engineered-derived products might vary considerably. Whereas products containing cells require extra controls and highly trained personnel, less complex products (composed solely by the scaffold material) might provide more versatility as they can have a defined and longer shelf life, be shipped, and manipulated without requiring advanced training. 


\section{MATERIALS AND METHODS}

This article provides a descriptive study comparing public regulatory policies in medical devices. The study includes a sample of five countries from Latin America: Brazil, Colombia, Ecuador, Mexico, and Peru. The comparative analysis of the regulation for medical devices for the evaluated countries was made based on documental evidence from national resolutions, decrees, laws, and other legal documents, as well as peer-reviewed publications, and international regulatory frameworks for medical devices. A policy diffusion model approach was employed to identify how regulatory policies in medical devices in general, and tissue engineered products in particular, have moved vertically (top-down) and horizontally throughout the region (16).

Findings from the study are presented in three main sections. The first section shows a brief summary of the international regulatory frameworks for medical devices and tissue engineered products. The framework includes a consensus table with the classification of medical devices based on their risk, level of invasiveness, and intended use. The second section presents results of the specific regulatory systems for each of the countries studied. The third section compares the above-mentioned diffusion model of the regulatory policies between the countries.

\section{RESULTS}

International Regulatory Frameworks for Medical Devices and Tissue Engineered Products 
The development of a common regulatory framework for assurance of effectiveness and safety of medical devices in a global perspective started in 1992, when a group of medical device regulatory authorities from the European Union, the United States, Canada, and Japan formed the Global Harmonization Task Force (GHTF), today identified as the International Medical Device Regulators Forum (IMDRF). The goal of GHTF was to generate a regulatory consensus for medical devices and practices involving medical devices (17). Likewise, an original aim was to provide assistance in the regulatory process for medical devices in developing countries (18). The harmonized guidelines include a definition of medical devices as,

... any instrument, apparatus, implement, machine, appliance, implant, in vitro reagent or calibrator, software, material or other similar or related article:

a) Intended by the manufacturer to be used, alone or in combination, for human beings for one or more of the specific purpose(s) of:

- Diagnosis, prevention, monitoring, treatment or alleviation of disease... or an injury, investigation, replacement, modification, or support of the anatomy or of a physiological process, supporting or sustaining life, control of conception, disinfection of medical devices, providing information for medical or diagnostic purposes by means of in vitro, examination of specimens derived from the human body; and

b) which does not achieve its primary intended action in or on the human body by pharmacological, immunological, or metabolic means, but which may be assisted in its intended function by such means (19).

Additionally, this guideline provides the final agreement on classification of medical devices based on risk assessment, which means, the probability of that device to generate damage and the 
evaluation of the severity of the harm produced. The classification system proposes four risk-based

categories (Table 1), and within each one, a comprehensive sub-classification according to invasiveness, bioactivity, and time of contact with the body. The classification and subclassification systems allow for a straightforward searching to determine the risk level of a specific medical device (19).

TABLE 1

ClassificAtion of MedicAl DEVICES IN THE HARMONIZATION CONSENSUS FROM THE GHTF (19)

\begin{tabular}{|c|c|c|c|}
\hline $\begin{array}{l}\text { Factor } \\
\text { Class }\end{array}$ & $\begin{array}{l}\text { Risk } \\
\text { Level }\end{array}$ & Invasiveness & Intended use \\
\hline \multirow[t]{3}{*}{$\mathbf{A}$} & Low Risk & Non-invasive & $\begin{array}{l}\text { Products that do not have contact with the patient or contact only } \\
\text { the intact skin. } \\
\text { Devices for channeling or storing blood, body liquids or tissues, } \\
\text { liquids, or gases for the purpose of eventual infusion, } \\
\text { administration or introduction into the body. } \\
\text { Devices that come into contact with injured skin if they are } \\
\text { intended to be used as a mechanical barrier, for compression or for } \\
\text { absorption of exudates. } \\
\text { Devices are manufactured from or incorporate non-viable animal } \\
\text { tissues or their derivatives that come in contact with intact skin only. }\end{array}$ \\
\hline & & $\begin{array}{l}\text { No surgically invasive } \\
\text { (used through body } \\
\text { orifices) }\end{array}$ & $\begin{array}{l}\text { Devices not intended for connection of an active medical device or } \\
\text { connected to a class A device, for a transient use. }\end{array}$ \\
\hline & & Surgically invasive & Reusable surgical instruments. \\
\hline \multirow[t]{3}{*}{$\mathbf{B}$} & $\begin{array}{l}\text { Low- } \\
\text { Moderate } \\
\text { Risk }\end{array}$ & Non-invasive & $\begin{array}{l}\text { Devices connected to a medical device in class B or higher. } \\
\text { Devices for storing or channeling blood or other body liquids or } \\
\text { for storing organs, parts of organs or body tissues. } \\
\text { Devices for filtration, centrifuging, or exchanges of gas or of heat } \\
\text { of blood, other body liquids or other liquids intended for infusion } \\
\text { into the body. } \\
\text { Devices that come into contact with injured skin devices } \\
\text { principally intended to manage the microenvironment of a wound. }\end{array}$ \\
\hline & & $\begin{array}{l}\text { No surgically invasive } \\
\text { (used through body } \\
\text { orifices) }\end{array}$ & $\begin{array}{l}\text { Devices not intended for connection of an active medical device or } \\
\text { connected to a class A device, for short-term use. } \\
\text { Devices that are intended to be connected to an active medical } \\
\text { device in class B or a higher class. }\end{array}$ \\
\hline & & Surgically invasive & $\begin{array}{l}\text { Devices intended for a transient or short-term use and designed for } \\
\text { a single use. } \\
\text { Implantable devices, and long-term surgically invasive devices } \\
\text { intended to be used in the teeth. }\end{array}$ \\
\hline
\end{tabular}




\begin{tabular}{|c|c|c|c|}
\hline $\begin{array}{l}\text { Factor } \\
\text { Class }\end{array}$ & $\begin{array}{l}\text { Risk } \\
\text { Level }\end{array}$ & Invasiveness & Intended use \\
\hline \multirow[t]{3}{*}{$\mathrm{C}$} & \multirow[t]{3}{*}{$\begin{array}{l}\text { Moderate- } \\
\text { High Risk }\end{array}$} & Non-invasive & $\begin{array}{l}\text { Non-invasive devices intended for modifying the biological or } \\
\text { chemical composition of blood, other body liquids or other liquids } \\
\text { intended for infusion into the body. } \\
\text { Non-invasive devices which come into contact with injured skin } \\
\text { intended to be used principally with wounds which have breached } \\
\text { the dermis and can only heal by secondary intent. }\end{array}$ \\
\hline & & $\begin{array}{l}\text { No surgically invasive } \\
\text { (used through body } \\
\text { orifices) }\end{array}$ & $\begin{array}{l}\text { Devices not intended for connection of an active medical device or } \\
\text { connected to a class A device, for long-term use. }\end{array}$ \\
\hline & & Surgically invasive & $\begin{array}{l}\text { Transient or short-term devices intended to supply energy as } \\
\text { ionizing radiation. } \\
\text { Transient devices intended to have a biological effect or be } \\
\text { partially/totally absorbed. } \\
\text { Short-term devices intended to have chemical changes in the body. } \\
\text { Transient or short-term devices intended to deliver medicines. } \\
\text { Implantable devices, and long-term surgically invasive devices. }\end{array}$ \\
\hline \multirow[t]{2}{*}{ D } & \multirow[t]{2}{*}{ High Risk } & $\begin{array}{l}\text { Non-invasive or } \\
\text { invasive }\end{array}$ & $\begin{array}{l}\text { All devices incorporating, as an integral part, a substance which, if } \\
\text { used separately, can be considered to be a medicinal product, and } \\
\text { which is liable to act on the human body with action ancillary to } \\
\text { that of the devices. } \\
\text { All devices manufactured from or incorporating animal or human } \\
\text { cells/tissues/derivatives thereof, whether viable or non-viable }\end{array}$ \\
\hline & & Surgically invasive & $\begin{array}{l}\text { Transient, short-term, or long-term devices intended to diagnose, } \\
\text { monitor, or correct a defect of the heart or of the central } \\
\text { circulatory system through direct contact with these parts of the } \\
\text { body. } \\
\text { Short-term or long-term devices intended to have a biological } \\
\text { effect or be partially/totally absorbed. } \\
\text { Short-term devices intended for use in direct contact with the } \\
\text { central nervous system. } \\
\text { Implantable and long-term devices intended to be life supporting } \\
\text { or life sustaining. } \\
\text { Implantable and long-term devices intended to administer } \\
\text { medicines. } \\
\text { Implantable and long-term devices intended to have chemical } \\
\text { changes in the body. }\end{array}$ \\
\hline
\end{tabular}

The harmonization does not explicitly include tissue engineered products, which are the focus of the present paper. However, they do present options in which these products could fit in a regulatory analysis. Specifically, they could be included into the group D, since they would contain animal- or human-derived cell or tissue components, bioactive components, and degradable materials. 
The term tissue engineering among regulatory policies for development, manufacturing, and commercialization of medical devices in a subset of Latin American countries: Brazil, Colombia, Ecuador, Mexico, and Peru, was identified. The mechanisms of classification of medical devices according to the factors identified for tissue engineered products in these countries were also studied for each country.

\section{Brazil}

In Brazil, the entity in charge of regulating manufacturing, packaging, imports, and commercialization of medical devices is the National Health and Surveillance Agency (ANVISA, Agência Nacional de Vigilância Sanitária). ANVISA was stablished in 1999 as an independent regulatory entity associated to the Ministry of Health. ANVISA regulates a broad spectrum of products and services in both health sectors (i.e., medical devices, and pharmaceuticals) and nonhealth sectors (e.g., agricultural and food) (20). In the area of pharmaceuticals, ANVISA received influences from the World Health Organization (WHO) and the Pan American Health Organization (PAHO) (20). In the context of medical devices, the selection of ANVISA as a regulatory institution was established under the Resolution RDC No. 185 of 2001, providing the orientations for registering, validating, and modifying the commercial rights of medical products in the country. According to this entity, a medical product is defined as any equipment, material, or system used to prevent, treat, or rehabilitate patients. Medical products cannot exert their main function through pharmacological, immunological, or metabolic means. Medical products are classified from I to IV, according to the intrinsic risk that they represent for patients using them (21). Both risk classification and sub-classification are similar to the guidelines established by the GHTF. 
Based on the proposed system of classification and considering the definition of tissue engineered products, those medical devices intended to accomplish functions of tissue repair would belong to class IV devices. The resolution includes the cases of biologic derived materials and combined materials with bioactive molecules (drugs). However, it does not consider regulatory mechanisms of complex tissue engineering applications where the cellular components are included.

Resolution RDC No. 56 of 2010 provides regulations for cell banks working with hematopoietic stem cells derived from bone marrow, peripheral blood, umbilical cord, or placenta, for autologous or allogeneic transplants (22). The use of hematopoietic stem cells is restricted to the correction of defects of the bone marrow or restoration of the hematopoiesis after chemotherapy processes involving damage of the myeloid and lymphoid precursors. The isolation of other cell types (e.g., mesenchymal stem cells) for therapeutic use in tissues other than blood, is not considered within the regulation, and therefore its application in tissue engineered approaches is limited.

In 2010, following an international trend in bio-therapeutic products lead by the WHO (23), ANVISA released Resolution RDC No. 55 to regulate the registration process of biological and biotechnological products in the country for marketing purposes. It includes both products manufactured in Brazil and imported from approved companies to commercialize them in the country. The final goal of the resolution is to guarantee quality and efficacy of biologic medicines, therefore ensuring safety of the patients (24). For instance, the regulation provides mechanisms to control hormones, growth factors, and bioactive molecules that could be used for tissue engineering applications. 


\section{Colombia}

In Colombia, the regulatory framework for the health sector is emitted by the National Ministry of Health and Social Protection (MHSP). Regulation for licensing for the production, processing, packaging, storage, commercialization, import/export, and maintenance of medical devices for human use is found in Decree No. 4,725 of 2005. Under this Decree, the MHSP conferred the National Institute of Medicine and Food Surveillance (INVIMA, Instituto Nacional de Vigilancia de Medicamentos $y$ Alimentos) the administrative power to execute regulatory functions on medical devices. INVIMA is also assigned the faculty to perform technical studies and analysis required to verify quality of medical devices, as well as to evaluate compliance of good manufacturing practices (GMP). Likewise, the Decree classifies medical devices according to potential risk (I: low, IIa: moderate, IIb: high, III: very high) associated with its use (25). Each of the categories is divided in a sub-classification system based on invasiveness of the medical device, which is comparable to the guidelines provided by the GHTF.

The parameters for manipulation of human tissues are established by Decree No. 2,493 of 2004. INVIMA is again the surveilling entity to evaluate methods of isolation, preservation, processing, storage, transportation, transplantation and/or implantation in recipient patients. The regulations include bone marrow and tissues other than blood. The institutions in charge of processing and storing the tissue samples are authorized tissue and bone marrow banks (non-profit institutions), which should guarantee GMP. The tissue and bone marrow banks are coordinated in a network centralized from the MHSP and that directly communicate with Health Care Service Institutions, the parties performing the surgical procedures to the patients (transplants or implants) (26). 
Specific guidelines of good practices within tissue and bone marrow banks were described under Resolution No. 5,108 of 2005 (27).

More recently, under Decree No. 1,782 of 2014, the country gave a step forward in the recognition of the importance of biotechnology in the development of new medical products, and stipulated the regulation for production and commercialization of biologic and biotechnological medicines. Biologic and biotechnological medicines include all cytokines, growth factors, and hormones, among others, that can be used to improve the performance of implanted biomaterials (28). The Decree is further reinforced with guidelines for the evaluation of immunogenicity of biologic medicines (Resolution No. 4,490 of 2016) (29), and a guideline for the evaluation of the stability of biologic medicines (Resolution No. 3,690 of 2016) (30). The regulation of biologic and biotechnological medicines, however, does not include products that, "contain or are exclusively formed by cells and/or non-viable human or animal tissues and that do not exert a function primarily pharmacologic, immunologic, or metabolic" (30). This exclusion, however, disclaims the bioactivity of naturally produced scaffolds, which have been shown to promote constructive remodeling of the tissue, as it has been shown by Sicari et al. (31). In fact, even though these are not "biologic medicines" as stated in the Resolution, they are composed mainly by proteins that are be recognized by host cells inducing an immune response.

\section{Ecuador}

In Ecuador, the regulation for medical devices and biologic products is centralized through the National Regulatory, Control, and Surveillance Health Agency (Agencia Nacional de Regulación, Control y Vigilancia Sanitaria). Under the Official Registry No. 573 of 2009, the regulation for 
commercialization of medical devices is provided. As indicated in the original document, these parameters were established following international norms such as those from the Food and Drug Administration of the United States (FDA), the International Council for Harmonization (ICH), the WHO, and the International Organization for Standardization (ISO) (32).

As seen for the other countries described in this article, medical devices are defined as articles, instruments, devices, or artifacts, for use in diagnosis, treatment, or prevention, to replace or modify the anatomy or physiological processes in the body. They are classified according to their use (therapeutic or diagnostic), invasiveness (non-invasive or invasive), and risk level (I: very low, II: moderate, III: high, IV: very critical) (33). The regulation, nevertheless, does not provide a comprehensive association between the classification criteria (use and invasiveness with risk level).

Additionally, the regulation does not have input about what is considered low, moderate, high, or critical risk, as well as neither the specific applications, uses, or considerations that should be analyzed to classify a medical device within each of the established parameters. Within the regulation, factors such as degradability of materials, combination of medical devices with drugs, and biologic materials are not considered either. Therefore, tissue engineered devices cannot be easily identified/classified within the local regulatory system.

The official Registry No. 21 of 2013 provides the regulation for commercialization of biologic medicines both locally and with other countries. Like in the other countries here described, the present regulation contains the framework for vaccines, biotechnological medicines, among 
others. Moreover, contrasting with the other countries, the Ecuadorian regulation includes a guideline for tissue engineering under Official Registry No. 745 of 2012. The regulation indicates that the National Institute of Donation and Organ Transplantation (INDOT, Instituto Nacional de Donación y Trasplante de Órganos) has the regulatory functions associated to organ donations and transplantations, and includes the topics of cell therapy, tissue engineering, and xenotransplantation. INDOT is also provided with the faculty to modulate activities of research in the field (33). Even though a general framework is included in the regulation, additional definitions framing the terms of tissue engineering and cell therapy, as well as the mechanisms by which research in the area is going to be focused, are needed.

\section{Mexico}

In Mexico, the regulations are distributed between three entities: the Federal Commission for the Protection against Risks in Health (COFEPRIS, Comisión Federal para la Protección contra Riesgos Sanitarios), the National Center for Transplants (CENATRA, Centro Nacional de Trasplantes), and the National Center for Transfusion of Blood (CNTS, Centro Nacional de Transfusión Sanguínea), all derived from the Ministry of Health (34). COFEPRIS covers medical devices. The institution has established a series of guidelines to provide the regulatory framework for certification of medical devices. Under the regulation, there is not an explicit description for tissue engineered products. Three levels of risk assessment (class I, II, and III) are described and combined with the levels of uncertainty (whether the medical device is commonly used in medical applications or has been recently introduced in the market, and whether it is dependent of material variations or dosage concentrations), invasiveness (non-invasive, invasive for less than 30 days, invasive products for more than 30 days) and safety (defined as "proved" or not in patients) (35). 
Based on the specific descriptions of the intended use, tissue engineered products will be ranked within class III, since it covers invasive materials that will last more than 30 days and that will partially or totally degrade exerting a biologic effect. Under the regulation of CENATRA, Mexico entered in the international efforts to control biologic medicines (36), within the exact same terms used in Brazil, Colombia, and Ecuador. Additional norms are found for the use of human organs and tissues for therapeutic purposes, specifically for transplants (37). Lastly, the CNTS is in charge of the norms regulating the acquisition and use of hematopoietic stem cells (38), but directives for other stem cells are not provided, generating a limitation in tissue engineering applications.

\section{Peru}

In Peru, pharmaceutical and medical devices are regulated under Law 29,459 of 2009. The entity in charge is the General Directorate of Medicines, Supplies, and Drugs (DIGEMID, Dirección General de Medicamentos, Insumos y Drogas). Herein, a medical device is defined as an instrument, machine, material, or any other article to be used in the treatment or alleviation of a disease or lesion. It also involves research, replacement, modification, or support of the anatomy or a physiological process (39). Both definitions could include the objective of a tissue engineered product, but the term was not explicitly stated.

Medical devices are classified according to the risk that they represent. Like in the definitions found for the equivalent regulation in other countries, medical devices are ordered as low, moderate, high, or critical risk potential (39). However, as occur with the regulation in Ecuador, the specific parameters that should define the risk levels are not explained in the Law. The same information is found in Decree 016-2011-SA, which regulates Law 29,459, and includes the 
consideration of risk level for medical devices as suggested in the GHTF (40), but the exact descriptions are not provided in the document.

The Decree also has the requirements for commercialization of biologic products. No additional information, compared to those found in other countries' regulations, is present here. Peru relies on the information provided by other countries, which the regulation frames as "countries with high sanitary surveillance," such as France, Holland, United Kingdom, United States, Canada, Japan, Switzerland, Germany, Spain, Italy, Belgium, Sweden, Norway, Australia, Portugal, Denmark, and Korea, to get the certificates to import products for commercialization in the country (40).

On the other hand, the National Organization for Donation and Transplants (ONDT, Organización Nacional de Donación y Trasplantes) was created as the entity in charge of the regulation of human tissue donation for therapy (approved by Law 28,189 of 2004) (41), bone marrow, and hematopoietic stem cells transplants (42).

\section{DISCUSSION}

The present paper provides a comparative study of the regulatory systems for medical devices, and specifically for tissue engineered products, within a subset of Latin American countries. From the documental evidence included in the analysis, it can be perceived the similarity of the regulation

for medical devices among the studied countries, especially in the system of classification of medical devices based on risk levels. The information, however, is more comprehensive in some countries (Brazil, Colombia, and Mexico) than in others (Ecuador and Peru), as indicated by the 
inclusion of sub-classifications of these devices based on invasiveness and intended use. These differences suggest both disparities in the process of policy adaptation between the compared countries and the necessity of a stronger support from international regulatory frameworks used as guidelines for the establishment of local policies.

A detailed comparison between the framework designed by the GHTF and the ones found in each of the countries studied, allows to identify diffusion patterns. Even though international frameworks represent a good effort to incorporate the regulation into the public policies of the countries, following a top-down diffusion pattern, important aspects involving complex medical devices, like those comprising the tissue engineered ones, were excluded from almost all the regulatory policies of Ecuador and Peru. For instance, the evolution of technologies in these countries or the importation processes of complex devices could be difficult or impossible.

More recently, and in order to overcome the problems of evaluation of complex medical devices, the Latin American region has initiated a program of cooperation and technical assistance, where the regulatory agencies of different countries have become articulated to help each other and to share information regarding medical devices introduced in the market of the region. The National Regulatory Agencies of Regional Reference (ARNR, Autoridades Reguladoras Nacionales de Referencia Regional) was founded by the regulatory agencies from Argentina, Brazil, Colombia, Cuba, and Mexico, in 2011 to accomplish these functions and help into the development of the region in terms of evaluation of quality and safety of medical devices. Since 2014, the ARNR has received help from the FDA and Health Canada in order to strengthen the regulatory capability of the region, provide technical cooperation to other regulatory agencies, and improve strategies of communication and diffusion of 
important material (43). The regional effort generated herein could be analyzed from a perspective of an Advocacy Coalition Framework (ACF) model, where the regulatory entities entered into coalition and strategically are forming learning processes or sharing regulatory information that facilitates the evaluation of medical devices into the region. The coalition helps them to be prepared for the rapid technological changes occurring in medical devices around the world, and to rapidly answer to alerts generated with specific medical devices in other countries.

The international coalitions seen here have been motivated among other factors, by established trade agreements between the involved countries. For example, the North American Free Trade Agreement (NAFTA) between the United States, Canada, and Mexico, makes this last country one of the main markets for imported medical devices coming from the United States (44). Similarly, the Common Market of the South (MERCOSUR, Mercado Común del Sur) formed by Argentina, Brazil, Uruguay, and Paraguay, looks for the generation of a harmonized market for medical devices among these countries (45).

Some other strategies of horizontal diffusion have been applied in the region to improve the quality of the regulatory processes regarding medical devices across borders. They can be evidenced for example with the activities that INVIMA is doing since 2013 with other regulatory agencies in Paraguay, Venezuela, Ecuador, Chile, Dominican Republic, Peru, Costa Rica, and Salvador, providing them with technical assistance and sharing with them its scientific and regulatory experience (43).

As seen with the topic of medical devices, similar experiences, and harmonization of strategies to regulate medicines are being in process worldwide. Pombo et al., (46) and Pineda et al., (47) have analyzed the regulatory frameworks of biological and biotechnological products in Latin American 
countries. In face of the challenges that globalization represents for quality control and safety of the final users of medical devices and medicines regulatory agencies around the world have congregated in the International Coalition of Medicines Regulatory Authorities (ICMRA) (48). ICMRA was created on 2013, and the active members are Brazil, Canada, China, European Union, France, Germany, Ireland, Italy, Japan, Korea, Mexico, the Netherlands, New Zealand, Nigeria, Singapore, South Africa, Switzerland, the United Kingdom, the United States, and the WHO. The objective of ICMRA is to help providing direction in regulatory process regarding medicines, traditional and emerging ones, sharing information and with a collaborative focus to globally advance in the research and development of the field (49). Particularly, ICMRA generates harmonized guidelines for regulatory processes regarding biologic and biotechnological medicines for public access. The utilization of these guidelines is of free decision from each country.

The coalition of countries with the goal of sharing experiences in medicines has not been unique from ICMRA. Since 1997 the Iberoamerican Network of Authorities in Medicines (Red EAMI, Red de Autoridades en Medicamentos de Iberoamerica) was formed, and now has 22 Iberoamerican countries participating: Andorra, Argentina, Bolivia, Brazil, Chile, Colombia, Costa Rica, Cuba, Ecuador, El Salvador, Guatemala, Honduras, Mexico, Nicaragua, Panama, Paraguay, Peru, Portugal Dominican Republic, Uruguay, and Venezuela (50).

\section{CONCLUSION}

The definition of tissue engineering is broad enough to allow the participation of different biomaterials, cells, and molecules, whose interaction represents a complex that is difficult to 
regulate. Immunological, pharmacological, and biocompatibility factors should be evaluated for each tissue engineered device to ensure safety and efficacy when used for clinical applications.

Regulatory mechanisms being applied in the reviewed Latin American countries have a strong influence from international regulations being applied through global coalitions among the regulatory agencies. Though less restricted and developed, a system of evaluation policies for tissue engineered products is evident. These differences provide a window of opportunity to apply clinical research that might not provide the safety and efficacy that should be warranted to the patients.

\section{RECOMMENDATIONS}

The present paper was limited to the evaluation of five countries within the Latin American region. Expansion of this analysis to other countries of the region is warranted in future studies.

\section{ACKNOWLEDGMENTS}

The author is grateful for the valuable contribution and edits from Dr. Jorge Enrique Delgado Troncoso, Professor of the Center for Latin American Studies at the University of Pittsburgh. Catalina Pineda Molina was supported by the Colciencias-Fulbright Scholarship and the Tuition Remission Fellowship from the University of Pittsburgh Center for Latin American Studies. 


\section{REFERENCES}

1. O'Brien FJ. Biomaterials \& scaffolds for tissue engineering. Materials Today. 2011 Mar; 14(3): 88-95. https://doi.org/10.1016/s1369-7021(11)70058-x

2. Arenas Gómez CM, Merizalde Soto GJ, Restrepo Múnera LM. Sustitutos cutáneos desarrollados por ingeniería de tejidos. Iatreia. 2012 Jan; 25(1): 42-53. Available from: http://www.scielo.org.co/scielo.php?script=sci_arttext\&pid=S0121$\underline{07932012000100005 \& \operatorname{lng}=\text { en. }}$.

3. Fontanilla MR, Suesca E, Casadiegos S. Desafíos para la implementación clínica de productos de ingeniería de tejidos en latinoamérica. In: de Sousa HC, Braga MEM, Sosnik A, editors. Biomateriales aplicados al diseño de sistemas tereapéuticos avanzados. Coimbra, Portugal: Coimbra University Press; 2015. pp. 701-725. https://doi.org/10.14195/978-989-26-0881-5

4. Shafiee A, Atala A. Tissue engineering: Toward a new era of medicine. Annu Rev Med. 2017 Jan; 68: 29-40. https://doi.org/10.1146/annurev-med-102715-092331

5. Markides H, McLaren J, Haj AJ. Overcoming translational challenges. The delivery of mechanical stimuli in vivo. Int $\mathrm{J}$ Biochem Cell Biol. 2015 Oct; 69: 162-172. https://doi.org/10.1016/j.biocel.2015.10.011

6. Sicari BM, Rubin JP, Dearth CL, Wolf MT, Ambrosio F, Boninger M, Turner NJ, Weber DJ, Simpson TW, Wyse A, Brown EH, Dziki JL, Fisher LE, Brown S, Badylak SF. An acellular biologic scaffold promotes skeletal muscle formation in mice and humans with volumetric muscle loss. $\quad$ Sci Translat Med. 2014 Apr; 6(234): 234 ra58. https://doi.org/10.1126/scitranslmed.3008085

7. Dahl S, Koh J, Prabhakar V, Niklason L. Decellularized native and engineered arterial 
scaffolds for transplantation. Cell Transplantation. 2003 Mar; 12(6): 659-66. https://doi.org/10.3727/000000003108747136

8. Cossu G, Birchall M, Brown T, De Coppi P, Culme-Seymour E, Gibbon S, Hitchcock J, Mason C, Montgomery J, Morris S, Muntoni F, Napier D, Owji N, Prasad A, Round J, Saprai P, Stilgoe J, Thrasher A, Wilson J. Lancet Commission: Stem Cells and Regenerative Medicine. Lancet. 2018 Mar; 391: 883-910. https://doi.org/10.1016/S0140-6736(17)31366-1

9. Pineda Molina C, Badylak SF. Translational smart materials in tissue engineering. In: Wang Q, editor. Smart materials for tissue engineering: Applications. London, United Kingdom: The Royal Society of Chemistry; 2017. pp. 39-66.

10. Londono R, Badylak SF. Factors which affect the host response to biomaterials. In: Badylak SF, editor. Host response to biomaterials. The impact of host response on biomaterial selection. Waltham, MA, USA: Elsevier; 2015. pp. 1-10.

11. Badylak SF. Decellularized allogeneic and xenogeneic tissue as a bioscaffold for regenerative medicine: factors that influence the host response. Ann Biomed Eng. 2014 Jul; 42(7): 151727. https://doi.org/10.1007/s10439-013-0963-7

12. Ratner BD, Hoffman AS, Schoen FJ, Lemons JE. Biomaterials science: An introduction to materials in medicine. $3^{\text {rd }}$ Ed. Waltham, MA, USA: Elsevier Science; 2013.

13. Williams DF. On the nature of biomaterials. Biomaterials. 2009 Oct; 30(30): 5897-909. https://doi.org/10.1016/j.biomaterials.2009.07.027

14. Scarritt ME, Pashos NC, Bunnell BA. A review of cellularization strategies for tissue engineering of whole organs. Front Bioeng Biotechnol. 2015 Mar; 3: 43-59. https://doi.org/10.3389/fbioe.2015.00043 
15. Gothard D, Smith EL, Kanczler JM, Rashidi H, Qutachi O, Henstock J, Rotherham M, El Haj A, Shakesheff K, Oreffo ROC. Tissue engineered bone using select growth factors: a comprehensive review of animal studies and clinical translation studies in man. Eur Cells Mater. 2014; 28: 166-208. https://doi.org/10.22203/eCM.v028a13

16. Cairney P, Heikkila T. A comparison of theories of the policy process. In: Sabatier PA, Weible CM, editors. Theories of the policy process, 3rd ed. Boulder, Colorado: Westview; 2014. pp. 363-387.

17. International Medical Device Regulators Forum. [cited 23 Oct 2017]. http://www.imdrf.org/index.asp

18. Cheng M. Medical Device Regulations: Global Overview and Guiding Principles. Geneva, Switzerland: World Health Organization; 2003.

19. GHTF/SG1/N29R16 Information Document Concerning the Definition of the Term "Medical Device." [Internet]. The Global Harmonization Task Force; 2005 [cited 2018 Mar 12]. http://www.imdrf.org

20. Moscou K, Kohler JC, MaGahan A. Governance and pharmacovigilance in Brazil: a scoping review. J Pharmaceutical Policy and Practice. 2016; 9: 3-17. https://doi.org/10.1186/s40545$\underline{016-0053-y}$

21. Manual do Usuário da Resolução-RDC No 185 [Internet]. Brasilia, Brasil: Ministério da Saúde, Agência Nacional de Vigilância Sanitária; 2001 [cited 2018 Mar 12]. http://portal.anvisa.gov.br

22. Resolução RDC n 56 [Internet]. Brasilia, Brasil: Ministério da Saúde, Agência Nacional de Vigilância Sanitária; 2010 [cited 2018 Mar 12]. http://portal.anvisa.gov.br

23. The Biotechnology Market in Brazil [Internet]. Resende V. United States of America: U.S. 
Commercial Service. Department of Commerce; 2012 [cited 2018 Mar 12]. https://www.nccommerce.com

24. Resolução RDC N 55 [Internet]. Brasil: Ministério da Saúde, Agência Nacional de Vigilância Sanitária; 2010 [cited 2018 Mar 12]. http://portal.anvisa.gov.br

25. República de Colombia. Decreto N. ${ }^{\circ} 4725$ por el cual se reglamenta el régimen de registros sanitarios, permiso de comercialización y vigilancia sanitaria de los dispositivos médicos para uso humano. Bogotá, Colombia: Ministerio de la Protección Social; 2005.

26. República de Colombia. Decreto N. ${ }^{\circ} 2493$ por el cual se reglamentan parcialmente las Leyes $9^{\text {a }}$ de 1979 y 73 de 1988, en relación con los componentes anatómicos. Bogotá, Colombia: Ministerio de la Protección Social; 2004.

27. República de Colombia. Resolución N. ${ }^{\circ} 5108$ por la cual se establece el manual de buenas prácticas para bancos de tejidos y de médula ósea y se dictan otras disposiciones. Bogotá, Colombia: Ministerio de la Protección Social; 2005.

28. República de Colombia. Decreto N. ${ }^{\circ} 1782$ por el cual se establecen los requisitos y el procedimiento para las Evaluaciones Farmacológica y Farmacéutica de los medicamentos biológicos en el trámite del registro sanitario. Bogotá, Colombia: Ministerio de la Protección Social; 2014.

29. República de Colombia. Resolución N. ${ }^{\circ} 4490$ por la cual se expide la "Guía de evaluación de la Inmunogenicidad para los Medicamentos Biológicos" y se dictan otras disposiciones. Bogotá, Colombia: Ministerio de la Protección Social; 2016.

30. República de Colombia. Resolución N. $^{\circ} 690$ por la cual se expide la guía de estabilidad de medicamentos biológicos. Bogotá, Colombia: Ministerio de la Protección Social; 2016. 
31. Sicari BM, Dziki JL, Siu BF, Medberry CJ, Dearth CL, Badylak SF. The promotion of a constructive macrophage phenotype by solubilized extracellular matrix. Biomaterials. 2014 Oct; 35(30): 8605-12. https://doi.org/10.1016/j.biomaterials.2014.06.060

32. República del Ecuador. Acuerdo Ministerial 205. Registro Oficial 573. Reglamento y control sanitario de dispositivos médicos y dentales [Internet]. Quito, Ecuador: Ediciones Legales, Ministerio de Salud Pública; 2009. http://www.controlsanitario.gob.ec

33. República del Ecuador. Decreto Ejecutivo 1205. Registro Oficial 745. Reglamento a ley orgánica de donación y transplante de órganos. Quito, Ecuador: Ediciones Legales, Ministerio de Salud Pública; 2012.

34. República de los Estados Unidos Mexicanos. Reglamento de la Ley General de Salud en materia de control sanitario de la disposición de órganos, tejidos y cadáveres de seres humanos [Internet]. Ciudad de México, México: Diario Oficial de la Federación, Presidencia de la República; 1985. [cited 2018 Mar 12]. http://www.salud.gob.mx

35. República de los Estados Unidos Mexicanos. Criterios para la clasificación de dispositivos médicos con base a su nivel de riesgo sanitario [Internet]. Ciudad de México, México; 2010. [cited 2018 Mar 12]. http://www.cofepris.gob.mx

36. República de los Estados Unidos Mexicanos. Acuerdo por el que se emiten los Lineamientos para autorizar la distribución o venta de lotes de productos biológicos [Internet]. Ciudad de México, México: Diario Oficial,, Secretaría de Salud; 2014. [cited 2018 Mar 12]. http://www.dof.gob.mx

37. República de los Estados Unidos Mexicanos. Reglamento de la Ley General de Salud en materia de trasplantes [Internet]. Ciudad de México, México: Diario Oficial, Presidencia de la República; 2014. [cited 2018 Mar 12]. http://www.salud.gob.mx 
38. Centro Nacional de la Transfusión Sanguínea [Internet]. Ciudad de México, México: Secretaría de Salud; 2012. [cited 2018 Mar 12]. http://cnts.salud.gob.mx

39. República del Perú. Ley N. ${ }^{\circ}$ 29,459. Ley de los productos farmacéuticos, dispositivos médicos y productos sanitarios. Lima, República del Perú: El Peruano, Congreso de la República; 2009.

40. República del Perú. Decreto Supremo N. 016-2011-SA. Lima, Perú: El Peruano, Ministerio de Salud; 2011.

41. República del Perú. Ley N. ${ }^{\circ}$ 28189. Ley general de Donación y Trasplante de Órganos y/o Tejidos Humanos. Lima, Perú: El Peruano, Congreso de la República; 2004.

42. República del Perú. Resolución Ministerial 520. Lima, Perú: El Peruano, Ministerio de Salud; 2014.

43. Instituto Nacional de Vigilancia de Medicamentos y Alimentos [Internet]. Bogotá, Colombia: 2016. [cited 2018 Mar 12]. Available from: https://www.invima.gov.co.

44. Brolin S. Global Regulatory Requirements for Medical Devices [Internet]. Västerås, Sweden: Department of Biology and Chemical Engineering, Mälardalen University; n.d. [cited 2018 Mar 12]. http://www.diva-portal.org/smash/get/diva2:121327/FULLTEXT01.pdfGlobal

45. Pombo ML, Di Fabio JL, Cortés MA. Review of regulation of biological and biotechnological products in Latin American and Caribbean countries. Biologicals. 2009 Jul; 37: 271-6. https://doi.org/10.1016/j.biologicals.2009.07.003

46. Pineda C, Caballero-Uribe CV, Gonclaves de Oliveira M, Lipszyc PS, Lopez JJ, Mataos Moreira MM, Feijo Azevedo V. Recommendations on how to ensure the safety and effectiveness of biosimilars in Latin America: a point of view. Clin Rheumatol. 2015 Feb; 34(4): 635-40. https://doi.org/10.1007/s10067-015-2887-0

47. Hamburg MA. New Realities of globalization. implications for health, medicine and the role 
of the regulator. London, England: Medicines and Healthcare Products Regulatory Agency (MHRA); 2014 [Internet]. https://www.gov.uk/government/organisations/medicines-andhealthcare-products-regulatory-agency

48. U.S. Department of Health \& Human Services. U.S. Food \& Drug Administration [cited 2018 Mar 12]. http://www.fda.gov

49. Pharmaceuticals and Medical Devices Agency [Internet]. International Coalition of Medicines Regulatory Authorities; 2017. [cited 2018 Mar 12]. http://www.icmra.info

50. Red de Autoridades en Medicamentos de Iberoamérica [Internet]. 2015. [cited 2018 Mar 12]. https://www.redeami.net 